\title{
GLYCOHEMOGLOBIN, HIPERTENSI, IMT TERHADAP GANGGUAN PENGLIHATAN PENDERITA DIABETES MELLITUS LANSIA
}

\author{
Glycohemoglobin, Hypertension, BMI toward Eyesight Disorder in Diabetes \\ Mellitus Patient of Elderly People
}

\author{
Rahmawati, Amiruddin \\ Peminatan Epidemiologi, Prodi Kesehatan Masyarakat, STIKES Mandala Waluya Kendari \\ (imma.sr85@gmail.com)
}

\begin{abstract}
ABSTRAK
Diabetes Mellitus (DM) berhubungan dengan gangguan penglihatan sebab kadar gula yang terus menerus sehingga mengakibatkan kerusakan pada pembuluh darah, saraf dan struktur internal lainnya. Faktor yang berhubungan dengan gangguan penglihatan pada penderita Diabetes Mellitus diantaranya adalah glycohemoglobin, hipertensi dan Indeks Massa Tubuh. Tujuan penelitian mengetahui hubungan glycohemoglobin, hipertensi, Indeks Massa Tubuh pada penderita Diabetes Mellitus lansia di Puskesmas Wua Wua. Jenis penelitian kuantitatif (analitik observasional) dengan menggunakan desain/rancangan penelitian cross sectional study. Populasi dalam penelitian ini adalah penderita Diabetes Mellitus lansia yang berobat di Puskesmas Wua - Wua Kota Kendari. Jumlah populasi sebayak 35, sampel terpilih sebanyak 26 responden. Uji statistik yang digunakan uji Spearman Rank. Responden melaksanakan pemeriksaan glycohemoglobin (HbAlc) dan pengukuran tekanan darah dan pengukuran Indeks Massa Tubuh. Tidak ada hubungan glycohemoglobin ( $\mathrm{HbAlc}$ ) dengan gangguan penglihatan pada penderita DM lansia $(\mathrm{p}=0,649)$, ada hubungan hipertensi dengan gangguan penglihatan pada penderita DM lansia $(\mathrm{p}=0,000)$, tidak ada hubungan indeks massa tubuh dengan gangguan penglihatan pada penderita DM lansia $(\mathrm{p}=0,103)$. Kesimpulan bahwa hipertensi ada hubungan dengan gangguan penglihatan pada penderita diabetes mellitus. Glycohemoglobin dan indeks massa tubuh tidak ada hubungan dengan gangguan penglihatan pada penderita diabetes mellitus.
\end{abstract}

Kata kunci : Glycohemoglobin, hipertensi, IMT, diabetes mellitus

\section{ABSTRACT}

The Diabetes Mellitus in touch with vision problems because sugar levels constant, resulting in damage to blood vessels, nerves and the internal structure of the other. The factors associated with impaired vision in patients with Diabetes to do some of them are Glycohemoglobin, hypertension and the index the Body. HbAlc as a factor is a very important role of. The purpose of research to identify how Glycohemoglobin for hypertension, the Massa's body in patients with Diabetes to do the Elderly in Community Wua Wua. This type of research is Kuantitatif (analytic observational) by using the Cross Sectional Study design. The population in this study is people with Diabetes to do the Elderly which medicines in the Community Wua - Wua (Kendari City). The number of population as many as 35. The sample selected as many as 26 of the respondents. Test of statistics used Spearman Rank. Respondents carry out the inspection Glycohemoglobin Alc (HbAlc) and the measurement of blood pressure and the measurement of the people's body. It's nothing to do Glycohemoglobin (HbAlc) with impaired vision in patients with diabetes mellitus Elderly $(p=0,649)$, there is a relationship for hypertension with impaired vision in patients with diabetes mellitus Elderly $(p=0,000)$. It's nothing to do body mass index with impaired vision in patients with diabetes mellitus Elderly $(p=0,103)$. Inconclusion hypertension has a siginificant association with eyesight disorder in diabetes mellitus patient. While, Glycohemoglobin and badi mass index do not have association with eyesight disorder in diabetes mellitus patient.

Keywords : Glycohemoglobin, hypertension, Body Massa's Indeks, diabetes mellitus 


\section{PENDAHULUAN}

Diabetes Mellitus (DM) yang umum dikenal sebagai kencing manis adalah penyakit yang ditandai dengan hiperglikemia (peningkatan kadar gula darah) yang terus-menerus dan bervariasi, terutama setelah makan. Diabetes mellitus merupakan keadaan hiperglikemia kronik disertai berbagai kelainan metabolik akibat gangguan hormonal, yang menimbulkan berbagai komplikasi kronik pada mata, ginjal, dan pembuluh darah, disertai lesi pada membran basalis dalam pemeriksaan dengan mikroskop elektron. ${ }^{1}$

Penderita Diabetes Mellitus di dunia pada tahun 2002 sekitar 171 juta dan diprediksikan akan mencapai 366 juta jiwa tahun 2030 sedangkan di Asia Tenggara terdapat 46 juta dan diperkirakan meningkat hingga 119 juta jiwa. ${ }^{2}$ Data di Indonesia dari 8,4 juta pada tahun 2000 diperkirakan menjadi 21,3 juta pada tahun 2030. Indonesia menempati urutan ke enam di dunia sebagai negara dengan jumlah penderita Diabetes Mellitus terbanyak. ${ }^{3}$

Secara epidemiologi, diperkirakan bahwa pada tahun 2030 prevalensi Diabetes Mellitus (DM) di Indonesia mencapai 21,3 juta orang. Hasil Riset kesehatan Dasar (Riskesdas) tahun 2007, diperoleh bahwa proporsi penyebab kematian akibat DM pada kelompok usia 45-54 tahun di daerah perkotaan menduduki ranking ke-2, yaitu $14,7 \%$ sedangkan daerah pedesaan. DM menduduki ranking ke-6, yaitu 5,8\%. Riskesdas 2007 juga menunjukkan penyebab kematian pada umur 65 tahun ke atas pada laki-laki adalah stroke $(20,6 \%)$, penyakit saluran nafas bawah kronik (10,5\%), Tuberkulosis Paru (TB) (8,9\%), hipertensi (7,7\%), NEC (7,0\%), penyakit jantung iskemik $(6,9 \%)$, penyakit jantung lain $(5,9 \%)$, diabetes mellitus $(4,9 \%)$, penyakit hati $(4,4 \%)$ dan pnemonia $(3,8 \%){ }^{4}$

Penyakit DM sering terjadi pada kaum lanjut usia. Diantara individu yang berusia $>65$ tahun, $8,6 \%$ menderita DM tipe II10. ${ }^{5}$ Laporan statistik dari International Diabetik Federation menyebutkan, bahwa sudah ada sekitar 230 juta orang pasien Diabetes Mellitus. Angka ini terus bertambah hingga $3 \%$ atau sekitar 7 juta orang tiap tahunnya. Dengan demikian, jumlah pasien DM diperkirakan akan mencapai 350 juta orang pada tahun 2025 dan setengah dari angka tersebut berada di Asia, terutama India, Cina, Pakistan dan Indonesia Prevalensi kasus Diabetes Mellitus di Su- lawesi Tenggara pada tahun 2011 sebanyak 3.334 kasus atau 1,3\%, pada tahun 2012 meningkat menjadi 3.501 kasus atau 1,6\%, dan tahun 2013 sebanyak 3.671 kasus atau 1,7\%. Penyakit Diabetes Mellitus merupakan salah satu penyakit dari 10 penyakit tertinggi di Sulawesi Tenggara. Angka morbiditas Diabetes Mellitus juga berada pada urutan ke-2 setelah hipertensi dari seluruh penyakit degeneratif yang ada di Sulawesi Tenggara. ${ }^{6}$ Diabetes Mellitus berhubungan dengan gangguan penglihatan sebab kadar gula yang terus menerus sehingga mengakibatkan kerusakan pada pembuluh darah, saraf dan struktur internal lainnya. Kerusakan pada pembuluh darah mata dapat menyebabkan gangguan penglihatan. ${ }^{7}$

Menurut Ozmen et al., menyimpulkan bahwa ada hubungan bermakna antara HbAlc dengan terjadinya retinopati diabetik. ${ }^{8}$ Penelitian Rusman Shiddiq, menyimpulkan bahwa hipertensi berhubungan dengan kejadian retinopati diabetik pada penderita Diabetes Mellitus di RSUD Prof. dr. Margono Soekarjo Purwokerto. ${ }^{9}$ Hasil penelitian Fathmi Adari Universitas Muhammadiyah Surakarta, menyimpulkan bahwa adanya hubungan yang bermakna antara IMT kadar gula darah pada penderita Diabetes Mellitus tipe 2. ${ }^{10}$ Tujuan penelitian untuk mengetahui hubungan glycohemoglobin hipertensi, Indeks Massa Tubuh pada penderita Diabetes Mellitus lansia di Puskesmas Wua Wua.

\section{BAHAN DAN METODE}

Penelitian dilaksanakan di Puskesmas WuaWua Kota Kendari Provinsi Sulawesi Tenggara. Populasi dalam penelitian ini adalah seluruh penderita Diabetes Mellitus yang berobat di Puskesmas Wua - Wua tahun 2015 sebanyak 35 orang. Jumlah sampel dalam penelitian ini sebanyak 26 responden dengan nilai d (tingkat kepercayaan/ ketepatan yang diinginkan) 0,1 . Pengambilan sampel dilaksanakan secara Simple Random Sampling. Uji statistik yang digunakan uji korelasi korelasi rank spearman.

Pengumpulan data dilaksanakan dengan menggunakan instrumen kuesioner dan pemeriksaan responden. Variabel Diabetes Mellitus dilakukan pemeriksaan glukosa darah sewaktu dengan menggunakan alat tes gula darah (Easy Touch). Variabel glycohemoglobin dilakukan dengan 
pengukuran $\mathrm{HbA} 1 \mathrm{c}$. Variabel Hipertensi dilakukan pemeriksaan tekanan darah dengan menggunakan tensi air raksa. Variabel Indeks Massa Tubuh dilakukan pengukuran dengan menggunakan timbangan dan meter. Analisis data menggunakan analisis univariat dan bivariat. Penyajian data yang dilakukan dalam bentuk narasi dan tabel.

\section{HASIL}

Berdasarkan karakteristik umur menunjukkan bahwa dari 26 responden kelompok umur tertinggi terdapat pada golongan umur 57-62 tahun sebanyak 8 responden $(30,8 \%)$ dan terendah pada golongan umur 68-71 tahun dan 72-77 tahun sebanyak 1 responden $(3,8 \%)$. Berdasarkan karakteristik jenis kelamin menunjukkan bahwa dari 26 responden terdapat 18 responden $(69,2 \%)$ responden berjenis kelamin perempuan dan 8 responden $(30,8 \%)$ berjenis kelamin laki - laki. Berdasarkan karakteristik pendidikan menunjukkan bahwa dari 26 responden tingkat pendidikan tertinggi terdapat pada responden tingkat SMU sebanyak 9 responden $(34,6 \%)$ sedangkan yang terendah pada yang tidak mengenyam sekolah sebanyak 1 responden $(3,8 \%)$ (Tabel 1).

Berdasarkan variabel glycohemoglobin (HbA1c) menunjukkan bahwa dari 26 responden HbAlc tertinggi adalah kategori buruk sebanyak 11 responden $(42,3 \%)$ sedangkan terendah adalah kategori sedang sebanyak 7 responden $(26,9$ $\%)$. Berdasarkan variabel hipertensi menunjukkan bahwa dari 26 responden yang menderita hipertensi sebanyak 9 responden $(34,6 \%)$ sedangkan yang tidak menderita hipertensi sebanyak 17 responden $(65,4 \%)$. Berdasarkan variabel Indeks Massa Tubuh menunjukkan bahwa dari 26 responden kategori indeks massa tubuh tertinggi adalah kategori normal sebanyak 12 responden $(46,2 \%)$ sedangkan terendah kategori ringan sebanyak 6 responden $(23,1 \%)$ (Tabel 1$)$.

Hasil penelitian menunjukkan bahwa dari 11 responden kategori buruk $\mathrm{HbA} 1 \mathrm{c}$ dengan gangguan penglihatan normal sebanyak 4 responden $(36,4)$, gangguan penglihatan ringan sebanyak 6 responden $(54,5 \%)$, gangguan penglihatan Berat sebanyak 1 responden $(9,1 \%)$. Dari 8 respoden kategori baik $\mathrm{HbAlc}$ dengan gangguan penglihatan normal sebanyak 4 responden $(50,0 \%)$, gangguan penglihatan ringan sebanyak 3 responden
(37,5\%) dan gangguan berat sebanyak 1 responden $(12,5 \%)$. Dari 7 responden kategori sedang $\mathrm{HbAlc}$ dengan gangguan penglihatan normal sebanyak 3 responden $(42,9 \%)$, gangguan penglihata ringan sebanyak 4 responden $(57,1 \%)$ dan gangguan penglihatan berat tidak ada responden. Berdasarkan hasil uji spearman didapatkan nilai korelasi spearman $=0.094$ dan nilai $\mathrm{p}=0.649$.

Tabel 1. Karakteristik Responden

\begin{tabular}{lcc}
\hline \multicolumn{1}{c}{ Karakteristik } & n (26) & \% \\
\hline Umur (tahun) & & \\
$45-50$ & 6 & 23,1 \\
$51-56$ & 7 & 26,9 \\
$57-62$ & 8 & 30,8 \\
$63-67$ & 3 & 11,5 \\
$68-71$ & 1 & 3,8 \\
$72-77$ & 1 & 3,8 \\
Jenis Kelamin & & \\
Perempuan & 18 & 69,2 \\
Laki - laki & 8 & 30,8 \\
Pendidikan & & \\
Tidak Sekolah & 1 & 3,8 \\
SD & 8 & 30,8 \\
SMP & 4 & 15,4 \\
SMU & 9 & 34,6 \\
PT & 4 & 15,4 \\
Glycohemoglobin & & \\
Baik & 8 & 30,8 \\
Sedang & 7 & 26,9 \\
Buruk & 11 & 42,3 \\
Hipertensi & & \\
Ya & 9 & 34,6 \\
Tidak & 17 & 65,4 \\
Indeks Massa Tubuh & & \\
Normal & 12 & 46,2 \\
Ringan & 6 & 23,1 \\
Berat & 8 & 30,8 \\
\hline
\end{tabular}

Sumber : Data Primer, 2016

Hal ini berarti bahwa tidak ada hubungan antara $\mathrm{HbA1c}$ dengan gangguan penglihatan pada penderita Diabetes Mellitus lansia di Puskesmas WuaWua (arah korelasi negatif) (Tabel 2).

Berdasarkan hasil penelitian menunjukkan bahwa dari 17 responden yang tidak hipertensi dengan penglihatan normal sebanyak 3 responden $(17,6 \%)$, gangguan penglihatan ringan sebanyak 12 responden $(70,6 \%)$ dan gangguan penglihatan Berat sebanyak 2 responden $(11,8 \%)$. Dari 9 responden menderita hipertensi dengan penglihatan 
Tabel 2. Hubungan Glycohemoglobin, Hipertensi, Indeks Massa Tubuh dengan Gangguan Penglihatan pada Penderita Diabetes Mellitus Lansia

\begin{tabular}{|c|c|c|c|c|c|c|c|c|c|}
\hline \multirow{3}{*}{ Variabel } & \multicolumn{6}{|c|}{ Gangguan Penglihatan } & \multirow{2}{*}{\multicolumn{2}{|c|}{ Jumlah }} & \multirow{3}{*}{$\mathbf{p}$} \\
\hline & \multicolumn{2}{|c|}{ Normal } & \multicolumn{2}{|c|}{ Ringan } & \multicolumn{2}{|c|}{ Berat } & & & \\
\hline & $\mathbf{n}$ & $\%$ & $\mathbf{n}$ & $\%$ & $\mathbf{n}$ & $\%$ & $\mathbf{n}$ & $\%$ & \\
\hline \multicolumn{10}{|l|}{ Gycohemoglobin } \\
\hline Baik & 4 & 50 & 3 & 37,5 & 1 & 12,5 & 8 & 100,0 & 0,649 \\
\hline Sedang & 3 & 42,9 & 4 & 57,2 & 0 & 0 & 7 & 100,0 & \\
\hline Buruk & 4 & 36,4 & 6 & 54,5 & 1 & 9,1 & 11 & 100,0 & \\
\hline \multicolumn{10}{|l|}{ Hipertensi } \\
\hline Ya & 8 & 88,9 & 1 & 11,1 & 0 & 0 & 9 & 100,0 & 0,000 \\
\hline Tidak & 3 & 17,6 & 12 & 70,6 & 2 & 11,8 & 17 & 100,0 & \\
\hline \multicolumn{10}{|c|}{ Indeks Massa Tubuh } \\
\hline Normal & 3 & 25,0 & 8 & 66,7 & 1 & 8,3 & 12 & 100,0 & 0,103 \\
\hline Ringan & 3 & 50,0 & 2 & 33,3 & 1 & 16,7 & 6 & 100,0 & \\
\hline Berat & 5 & 62,5 & 3 & 37,5 & 0 & 0 & 8 & 100,0 & \\
\hline
\end{tabular}

Sumber : Data Primer, 2016

normal sebanyak 8 responden $(88,9 \%)$, gangguan penglihatan ringan sebanyak 1 responden $(11,1 \%)$ dan gangguan berat tidak ada responden). Berdasarkan hasil uji spearman didapatkan nilai korelasi spearman $=0.669$ dan nilai $\mathrm{p}=0.000$. Hal ini berarti ada hubungan secara positif antara hipertensi dengan gangguan penglihatan pada penderita diabetes mellitus lansia di Puskesmas Wua-Wua dengan kekuatan korelasi sedang (Tabel 2).

Berdasarkan hasil penelitian menunjukkan bahwa dari 12 responden Indeks Massa Tubuh (IMT) kategori normal penglihatan normal sebanyak 3 responden $(25,0 \%)$, gangguan penglihatan ringan sebanyak 8 responden $(66,7 \%)$, dan gangguan penglihatan berat sebanyak 1 responden $(8,3 \%)$. Dari 8 responden Indeks Massa Tubuh kategori berat dengan penglihatan normal sebanyak 5 responden $(62,5 \%)$, gangguan penglihatan ringan sebanyak 3 responden (37,5\%) dan gangguan penglihatan berat tidak ada responden. Dari 6 responden Indeks Massa Tubuh kategori ringan dengan gangguan penglihatan normal sebanyak 3 respoden $(50,0 \%)$, gangguan penglihatan ringan sebanyak 2 responden $(33,3 \%)$ dan gangguan penglihatan berat sebanyak 1 responden $(16,7 \%)$. Berdasarkan hasil uji spearman didapatkan nilai korelasi spearman $=-.327$ dan $\mathrm{p}=0.103$. Hal ini berarti tidak ada hubungan antara Indeks Massa Tubuh dengan gangguan penglihatan pada penderita diabetes mellitus lansia di Puskesmas Wua - Wua (arah korelasi negatif) (Tabel 2).

\section{PEMBAHASAN}

Sebuah glycohemoglobin tes, atau hemoglobin A1c, adalah tes darah yang memeriksa jumlah gula (glukosa) terikat pada hemoglobin dalam sel darah merah. Ketika hemoglobin dan ikatan glukosa, mantel membentuk gula pada hemoglobin kemudian mantel yang tebal akan ada lebih banyak gula dalam darah. Tes A1c mengukur seberapa tebal mantel selama 3 bulan terakhir, yang merupakan lama kehidupan sel darah merah.Orang yang memiliki diabetes atau kondisi lain yang meningkatkan kadar glukosa darah mereka memiliki lebih banyak glycohemoglobin (gula terikat pada hemoglobin) dari biasanya. ${ }^{11}$

Berdasarkan analisis univarat bahwa masih banyak responden menderita Diabetes Mellitus yang tidak terkontrol, pengendalian Diabetes Mellitus masih kurang. Hal ini disebabkan, responden tidak memiliki pola hidup sehat dan seimbang, tidak memperhatikan jenis makanan dan minuman yang dikonsumsi. Responden tidak melakukan diet, olahraga, makan obat yang tidak patuh lagi. Selain itu, responden juga beranggapan bahwa bila gula darah sudah dikatakan normal, maka responden sering menganggap penyakitnya sudah sembuh. Berdasarkan hasil analisis bivariat menunjukkan bahwa Diabetes Mellitus tidak terkontrol sehingga berisiko tinggi mengalami komplikasi jangka panjang, seperti gangguan pada mata, ginjal, pembuluh saraf, dan gangguan pada jantung. HbAlc merupakan suatu faktor penting yang berpengaruh terhadap gangguan penglihatan. Hal ini 
disebabkan HbA1c merupakan suatu petanda untuk mengetahui kontrol kadar glukosa darah penderita.

Berdasarkan hasil uji spearman didapatkan korelasi hal ini berarti bahwa tidak ada hubungan antara $\mathrm{HbAlc}$ dengan gangguan penglihatan pada penderita Diabetes Mellitus lansia di Puskesmas Wua - Wua (arah korelasi negatif). Hal ini berarti bahwa pengontrolan gula darah tidak menyebabkan terjadinya gangguan penglihatan pada penderita Diabetes Mellitus. Menurut hasil pengamatan pada saat penelitian bahwa ada faktor lain yang menyebabkan sehingga HbA1c tidak berhubungan dengan gangguan penglihatan yakni metode pemeriksaan mata, variasi metabolisme responden dan lama menderita Diabetes Mellitus karena semakin lama seseorang menderita Diabetes Mellitus, semakin besar akan mengalami gangguan penglihatan.

Hasil peneilitian ini sejalan dengan penelitian Rhusmasn Shiddiq, dkk, yang menyimpulkan bahwa tidak ada hubungan (HbA1c) dengan kejadian retinopati diabetik pada penderita diabetes melitus di RSUD Margono Soekarjo Purwokerto. Hasil Penelitian ini tidak sejalan dengan penelitian Refa Safaruddin \& Dewi NA yang menyimpulkan bahwa terdapat hubungan yang signifikan antara $\mathrm{HbA} 1 \mathrm{c}$ dengan derajat berat retinopati diabetika. ${ }^{12}$

Hipertensi dapat menyebabkan kerusakan pada pembuluh di retina, di daerah belakang mata. Tekanan darah tinggi dapat merusak pembuluh memasok darah ke retina sehingga menyebabkan retinopati hipertensi. Kondisi ini dapat menyebabkan perdarahan di mata, penglihatan kabur dan kehilangan lengkap visi. Berdasarkan analisis univariat menunjukkan bahwa sebagian besar responden hipertensi terkontrol, responden rutin melakukan pemeriksaan tekanan darah. Responden mampu menghindari faktor pencetus hipertensi, yakni pola makan, stres. Selain itu, responden rutin mengonsumsi obat penurun darah.

Berdasarkan hasil analisis bivariat yang tidak hipertensi, tetapi mengalami gangguan penglihatan hal ini disebabkan oleh faktor umur lansia. Bertambahnya usia akan memengarui fungsi organ pada mata khususnya pada usia lansia, fungsi kerja pupil akan mengalami penurunan $2 / 3$ dari pupil orang dewasa atau muda, penurunan tersebut meliputi ukuran - ukuran pupil dan kemampuan melihat dari jarak jauh. Proses akomodasi merupakan kemampuan untuk melihat benda - benda dari jarak dekat maupun jauh. Akomodasi merupakan hasil koordinasi atas ciliary body dan otot - otot, apabila seseorang mengalami penurunan daya akomodasi maka orang tersebut disebut presbiopi.

Berdasarkan hasil uji nilai korelasi hal ini berarti, ada hubungan secara positif antara hipertensi dengan gangguan penglihatan pada penderita Diabetes Mellitus lansia di Puskesmas Wua - Wua dengan kekuatan korelasi sedang. Hipertensi dapat menyebabkan beberapa gangguan atau kelainan pada mata seperti gangguan otot - otot penggerak bola mata terjadi karena kelumpuhan saraf otot penggerak bola mata tersebut terutama nervus VI dan akibatnya terjadi penglihatan ganda (diplopia). Selain itu, hipertensi dapat menyebabkan kelainan pada retina yang disebut dengan gangguan retinopati hipertensi. Retinopati hipertensi adalah kelainan - kelainan yang terjadi pada retina (yang merupakan saraf) karena perubahan pada pembuluh darah retina akibat hipertensi tersebut. Keadaan hipertensi yang berkepanjangan pada penderita Diabetes Mellitus menyebabkan perubahan pada mikrovaskular. Perubahan yang terjadi pada mikrovaskular, yaitu berupa penurunan kemampuan otot polos mikrovaskular dalam menyeimbangkan perubahan aliran darah. Mikrovaskular dalam keadaan kaku terus menerus, sehingga terjadi gangguan perfusi nutrisi dan oksigen di jaringan yang diperdarahi oleh mikrovaskular seperti retina. ${ }^{13}$ Hasil peneilitian ini sejalan dengan penelitian Rhusmasn Shiddiq, dkk., yang menyimpulkan bahwa ada hubungan hipertensi dengan kejadian retinopati diabetik pada penderita diabetes melitus di RSUD Margono Soekarjo Purwokerto.

Berdasarkan hasil analisis univariat menunjukkan bahwa sebagian responden memiliki berat badan ideal karena responden sebagaian besar memiliki berat badan dan tinggi badan yang ideal selain itu umur lansia dan pekerjaan memengaruhi dari indeks massa tubuh. Berdasarkan hasil analisis bivariat menunjukkan bahwa Indeks Massa Tubuh normal, tetapi ada gangguan penglihatan hal ini disebabkan faktor umur yang berada pada usia lansia. Kornea, lensa iris, aquous humormvitorous humor akan mengalami perubahan seiring 
bertambahnya usia, karena bagian utama yang mengalami perubahan/penurunan sensifitas yang menyebabkan lensa pada mata, produksi aquosus humor juga mengalami penurunan, tetapi tidak terlalu terpengaruh terhadap keseimbangan dan tekanan intra okuler lensa umum. Bertambahnya usia akan memengarui fungsi organ pada mata khususnya pada usia lansia, fungsi kerja pupil akan mengalami penurunan $2 / 3$ dari pupil orang dewasa atau muda, penurunan tersebut meliputi ukuran - ukuran pupil dan kemampuan melihat dari jarak jauh. Proses akomodasi merupakan kemampuan untuk melihat benda - benda dari jarak dekat maupun jauh. Akomodasi merupakan hasil koordinasi atas ciliary body dan otot - otot, apabila seseorang mengalami penurunan daya akomodasi maka orang tersebut disebut presbiopi. Selain itu ditemukan Indeks Massa Tubuh berat, tetapi gangguan penglihatan normal hal ini disebabkan responden rajin memeriksa mata dan mengonsumsi obat mata. ${ }^{14}$

Berdasarkan hasil uji spearman didapatkan hasil bahwa tidak ada hubungan antara Indeks Massa Tubuh dengan gangguan penglihatan pada penderita diabetes mellitus lansia di Puskesmas WuaWua (arah korelasi negatif). Hal ini berarti bahwa berat badan dan tinggi badan tidak menyebabkan terjadinya gangguan penglihatan pada penderita diabetes mellitus lansia. Menurut peneliti bahwa faktor yang menyebabkan sehingga indeks massa tubuh tidak ada hubungan yakni karena aktivitas fisik responden yang baik. Berdasarkan hasil wawancara bahwa aktivitas fisik responden perempuan cukup aktif yakni karena pekerjaan sebagai ibu rumah tangga banyak hal yang harus dikerjakan urusan rumah tangga mulai dari pekerjaan di rumah, mengurus suami dan anak, dan pekerjaan di luar rumah karena responden ada yang membantu suami mencari nafkah. Penelitian ini tidak sejalan dengan penelitian Adnan Miftahul, dkk bahwa ada hubungan antara Indeks Massa Tubuh (IMT) dengan kadar gula darah penderita DM tipe 2 dengan nilai $\mathrm{p}=0,000$ atau $\mathrm{p}<0,05 .^{15}$

\section{KESIMPULAN DAN SARAN}

Hasil penelitin menunjukkan bahwa tidak ada hubungan glycohemoglobin dengan gangguan penglihatan pada penderita diabetes mellitus lansia di Puskesmas Wua - Wua. Ada hubungan hipertensi dengan gangguan penglihatan pada penderita diabetes mellitus lansia di Puskesmas Wua - Wua. Tidak ada hubungan Indeks Massa Tubuh dengan gangguan penglihatan pada penderita diabetes mellitus Lansia di Puskesmas Wua - Wua. Saran yang dapat direkomendasikan, yakni glycohemoglobin tidak ada hubungan dengan gangguan penglihatan pada penderita diabetes mellitus lansia diharapkan para penderita diabetes mellitus tetap melakukan pengendalian diabetes mellitus salah satunya dengan cara pola hidup sehat dan seimbang. Diharapkan pada penderita diabetes mellitus mengontrol tekanan darah secara teratur. Walaupun Indeks Massa Tubuh tidak ada hubungan dengan gangguan penglihatan pada penderita diabetes mellitus diharapakan para penderita diabetes mellitus mempertahankan berat badan Ideal dengan menjaga pola makan.

\section{UCAPAN TERIMA KASIH}

Penulis menyampaikan dengan penuh rasa hormat, mengucapkan terima kasih yang tidak terhingga. Ucapan terima kasih yang sebesar-besarnya penulis sampaikan pula pada : Pihak yayasan Mandala Waluya yang telah memberikan kesempatan kepada kami dalam melaksanakan tridharma perguruan tinggi hususnya dibidang pendidikan. Pihak STIKES Mandala Waluya yang telah memberikan kesempatan kepada para dosen untuk mengembangkan diri melalui penelitian yang tentukan dapat menambah wawasan dalam mengembangkan diri. Pihak LPPM yang senantiasa memberikan dorongan dan motivasi demi mengembangkan karier dosen melalui program program pengabdian masyarakat dan penelitian dosen. Pihak Puskesmas Wua - Wua Kota Kendari. Pihak Lab. Prodia. Teman-teman dosen dan mahasiswa STIKES Mandala Waluya, terimakasih atas motivasi dan dukungannya.

\section{DAFTAR PUSTAKA}

1. Bilous. Diabetes Mellitus. Seri Kesehatan Bimbingan Dokter Pada Diabetes. Jakarta; 2002.

2. Sarah Wild, MB BCHIR, PHD dkk. Global Prevalence of Diabetes, Estimates for the Year 2000 and Projections for 2030. Diabetes Care:2007.

3. Kemenkes RI. Diabetes Melitus Penyebab Ke- 
matian Nomor 6 di Dunia. Jakarta: Kementrian Kesehatan RI; 2013.

4. Depkes RI,.Riset Kesehatan Dasar. Jakarta: Departemen Kesehatan RI; 2007.

5. KurniawanI. Diabetes Mellitus tipe 2 pada usia lanjut, Majalah kedokteran Indonesia, 2010:60(12):576-84.

6. Dinkes Prov. Sultra. Profil Kesehatan 2013. Sulawesi Tenggara : Dinas Kesehatan Provinsi Sultra; 2013.

7. Fay. Gangguan Penglihatan pada Pasien Tipe I. Klinik Keluarga, 09 Oktober 2014.

8. Ozmen B, Guclu F, Kafesciler S, Ozmen D, Hekimsey. The Relationship Between glycosylated Haemoglobin and Diabeteic Retinopathy in Patient With Type 2 Diabetes. Turk Jem. 2007;11:10-15.

9. Shiddiq R, Heru WW, Bambang P. Hubungan hipertensi dan Glycohemoglobin (HbA1c) dengan kejadian Retinopatik Diabetik pada penderita Diabetes Mellitus di RSUD Margono SoekarjoPurwokerto. Mandala of Health.
2011;5(3):1-5.

10. Fathmi A. Hubungan IMT dengan Kadar Gula Darah pada Penderita Diabetes Mellitus Tipe 2 di RSU Daerah Karanganyar [Skripsi]. Surakarta : Universitas Muhammadiyah Surakarta; 2012.

11. Anonim. Glycohemoglobin. Healthwise, 7 Oktober 2013.

12. Refa S,Dewi NA. Hubungan Antara HbA1c dan Kadar Lipid Serum dengan Derajat Berat Retinopati Diabetika. Jurnal Kedokteran Brawijaya. 2015;XXI(3):138-44.

13. Anonim.Pengaruh Hipertesi pada Mata. Bikers Pintar, 13 Novemebr 2014.

14. Bagus. Gangguan Penglihatan. Blogspot, 06 Mei 2016.

15. Adnan M, Mulyati T, Joko TI. Hubungan Indeks Massa Tubuh (IMT) dengan Kadar Gula Darah Penderita Diabetes Mellitus DM tipe 2 Rawat Jalan di RS Tugurejo Semarang. Jurnal Gizi Universitas Muhammadiyah Semarang. 2013;2(1):138-24. 